\title{
A Conceptual Development of Entrepreneurship Education and Entrepreneurial Intentions among Malaysian University Students
}

\author{
Dr. Parimala Rengiah, Assoc. Prof. Dr. Ilham Sentosa \\ Southern Cross University, Australia; City University College of Science and Technology Malaysia
}

\begin{abstract}
The purpose of this study is to examine the significant factors influencing Malaysian university students' intentions to venture into business through entrepreneurship education. Malaysia is a developing nation has a high rate of unemployment among the young graduates emerging from the universities. The Malaysian government is taking great efforts in transforming into a knowledge-based economy, where the term 'entrepreneur' has been defined as one of its key elements. The problem is how to instil in the minds of students that they should venture into business instead seeking jobs. The literature probes into concepts and conceptualisations of the theories and has proposed a theoretical framework identifying the research issues and the research gap. The research design consists of developing a hypothetical framework with entrepreneurship education as the independent variables to test the dependent variable of entrepreneurial intentions. In addition, demographic characteristics, attitude factors and stakeholder support system factors act as mediating variables. The methodology employed is quantitative, which includes a random sample from final year students studying entrepreneurship as a subject curriculum from four entrepreneurial focused Malaysian universities. Data collection is proposed using questionnaire survey and analysed through SPSS version 22.0 and Structural Equation Modelling, AMOS version 22.0.
\end{abstract}

Keywords: Entrepreneurship education, entrepreneurial intentionsstructural equation modelling

\section{Introduction}

Entrepreneurship education has expanded significantly in most of the countries during the last two decades. The considerable expansion over this period has been seen as a widespread governmental belief in the positive impact that entrepreneurship has on the socio-economic and political infrastructure of a nation [1]. There has been an increase in entrepreneurship education throughout the globe. Globalisation has brought about many substantial changes in the job market to which young people as newcomers are vulnerable. With the continuously changing environment, the students of the current century find that university education is no longer secured for employment in the job market [2].

Entrepreneurship education has come a long way since the first entrepreneurship course proposed in Harvard university in 1971 [3]. Entrepreneurship has become and academic and teaching field [4], considering the fast increasing number of universities worldwide, which offer entrepreneurship programs and courses. The current figures show a real boom in entrepreneurship education and training in many countries in the world [5]. Universities play a major role in regional innovation and economic growth. They are the key providers of new technologies and business ventures; and sometimes act as a regional development engine [6]. Entrepreneurial intent has been proven to be a predictor of future entrepreneurial behaviour [7]. Intent can be described as 'a state of mind directing a person's attention toward a specific object or a path in order to achieve something' [8]. Previous studies on intentions have focused on understanding its importance an impact on individuals and graduate students to start businesses [9, 10]. Though empirical research supports many factors, but it is not known what drives the students' career decision toward self-employment. A central question that arises is that what factors determine the entrepreneurial intent among students.

In Malaysia, entrepreneurship education has been growing in importance. One of the main social development problems facing the Malaysian economy is graduate unemployment. Graduate preference to become paid employees over becoming self-employed and the current universities systems that promote learning are believed to be among the several contributing factors to the current problems [11]. Realising the significance of entrepreneurship in the development of the knowledge-based economy in Malaysia, efforts have been taken to nurture entrepreneurship in all ways. The higher educational institutions in the country started offering formal entrepreneurship education and included it as one of the subjects in the curriculum of business and other courses, organizing seminars, conferences, short courses and training for students [12]. All stakeholders, civil society, private sector and the governments ensure that entrepreneurship continues to flourish in today's society. In addition to this the role of universities promoting entrepreneurship education to students is increasing [13]

The problem statement therefore could be stated as, 'the effectiveness of entrepreneurship education in developing entrepreneurial intentions among the Malaysian university students'. The issue, 'can 
entrepreneurship be taught?' has been a fundamental issue of debate. The management education can contribute to the provision of entrepreneurship education, technical skills and competencies in the higher educational institutions, but whether the students have the intention to become future entrepreneurs have to be examined. The objective of this study is to examine the key factors influencing students' intent to create a new venture. Entrepreneurship education studies in the universities have been explored across campuses in universities by many researchers. A linear regression method was proposed and a significant positive correlation was found between participation in entrepreneurial programs and venture creation by Weaver [14]. Entrepreneurship education has been the focus on how to start a business with entrepreneurial behaviour and intention [15]. Previous researches have explored personality traits and attitudes [16]. Social factors such as personal background, family background, stage of career, early life experience and environmental factors have been examined with entrepreneurial intent [17]. Most of the studies conducted in the past had tested the factors separately with entrepreneurial intention. Considering the studies and the literature of concepts and conceptualisations on the theories, a theoretical framework has been developed. With these factors in mind, examining how the effectiveness of entrepreneurship education and its contributing factors can influence entrepreneurial intention is the significance of the study.

\subsection{Underlying Theories}

\section{Literature Review}

The literature reviews some of the underlying theories relating to entrepreneurship and entrepreneurial intentions. The main theory used in this study is the 'theory of planned behaviour' [18]. Many researchers have used to test the model of this theory to test entrepreneurial intentions [19]. It was indicated that attitudes towards behaviour and perceived behavioural control were affected by subjective norms to perform the behaviour.. Another theory is McClelland's 1961 theory of achievement which states that individuals with strong need for achievement, affiliation and power [20]. The psychological and behavioural characteristics were depicted in individuals with an ideal type of entrepreneurial personality [21]. Other theories relating to entrepreneurship includes the theory of Social Cognition by Bandura 2001 [22], and the theory of Social Learning by Wenger 1991 [23]. These theories depicted the conceptualisation that learning was considered as an informationprocessing activity through knowledge transmission and assimilation with a network of social relationships. Another prominent model, the personality traits model described the characteristics relating to an entrepreneur such as motivation for achievement, internal locus of control, risk-taking and tolerance of ambiguity [23].

Some researchers proposed theories relating to entrepreneurship. They indicated the entrepreneur's image and encouragement of university environment that affect entrepreneurial intention among university students [24, 25]. An economic-psychological model which included factors influencing individuals' intention to start a business through entrepreneurial conviction was proposed by Krueger 1993 [26], and Davidsson 1995 [27]. Kolvereid 1996 [28] looked at the influence of demographic variables such as family background, gender and previous self-employment experience [29].

Recently entrepreneurial intentions have received considerable interests among researchers [29]. Previous studies showed that entrepreneurship were cultivated during their lifetime and education became very important to build entrepreneurship in people's mind [30]. Educational background is a key variable and is included in the analysis of researchers $[28,32]$.

\subsection{Conceptual Development To The Hypothetical Model}

Entrepreneurship education studies in the universities had been explored across campuses in universities by many researchers. The debate in the entrepreneurship academy was whether entrepreneurship could be taught. It had been critiqued by many researchers as it was related to a matter of personality and psychological characteristics that cannot be taught [33]. Contradicting this statement, many researchers argued and suggested that' entrepreneurship or certain facets of it can be taught as a subject [5]. The body of knowledge on entrepreneurship education was focussed on specific objectives to train individuals for, about or in entrepreneurship, through appropriate teaching methods and finally to establish success indicators and methods of evaluation and impact measurements [1].

It was found that a typical university setting was unlikely to include many entrepreneurial elements. The budding entrepreneur needed not only knowledge (science), but new ways of thinking, new kind of skills and new modes of behaviour (arts). Traditional methods were found to be insufficient, so they had to be complemented with entrepreneurial approaches [34]. Multidisciplinary approaches were promoted outside the business schools in entrepreneurship education that focused on the entrepreneurial-directed approach involving co-learning between the teachers and students and experience organised on the basis of theory and learning [35].

Past researches had examined the psychological factors; such as personality traits, self-efficacy and risk taking propensity as characteristics of an entrepreneurial intentions [36]. There was a belief that entrepreneurs possess unique values and attributes. These needed drives to behave in such a way, and had been argued that 
they cannot be merely developed or trained in classroom settings. It was found that individuals with high needs of control, achievement, the ability to take risks and a tolerance for ambiguity had been seen to have the drive for entrepreneurial activity [37] As an alternative the attitude measures became a predictive behaviour and social cognition and cognitive processes as significant factors in career choice [38]. Environmental and support factors were also found to influence entrepreneurial behaviour. A hostile environment and good financial support increased the individual's intention towards self-employment [39].

From the identification and review of the literature, analysing the research problem, and studying the relevant theories and models, a theoretical framework had been proposed to test the model for the research topic. Seven hypotheses were developed in the model with the following variables. The exogenous variables were classified as entrepreneurship education which included the components of entrepreneurship curriculum, teaching methodology and university's role in promoting entrepreneurship. Mediating variables included were demographic factors of students, the components being gender, family history and ethnicity; attitude factors, the components being attitude towards money, change and competitiveness and stakeholder support system factors, the components of government support, financial institutions support and parents of students support to test the model. The endogenous variable tested was the entrepreneurial intent of students in the university (refer Fig. 1)

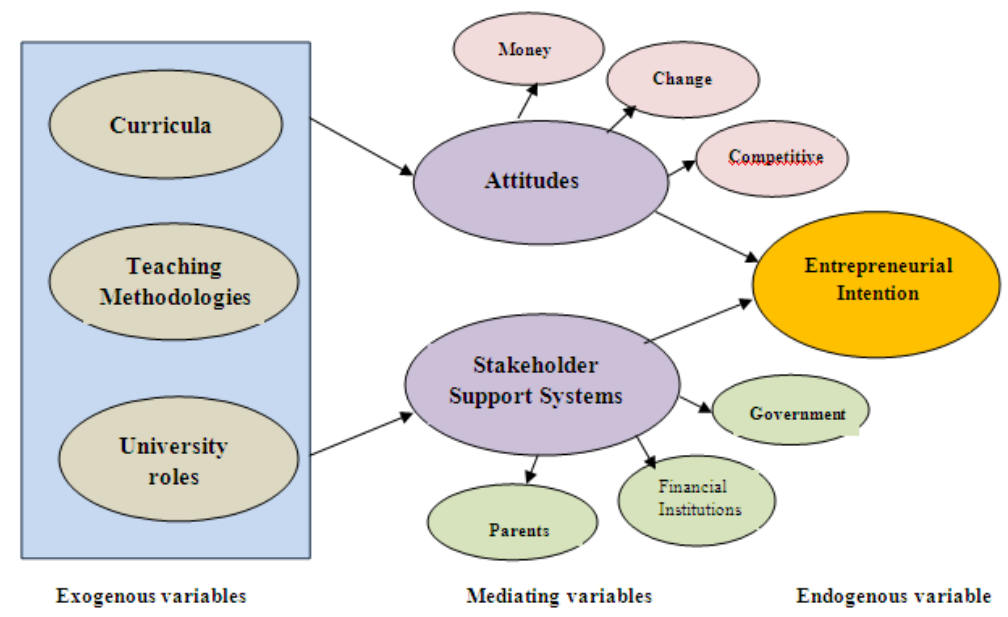

Figure 1 Proposed Hypothetical Model

\subsubsection{Exogenous Variables}

\section{i) Entrepreneurship curriculum}

Entrepreneurship education has increased significantly in most industrialised countries through providing courses related to curricula. It is concerned with learning and facilitating entrepreneurship (what to do and how to make it happen) and less studying about it. These approaches are not sufficient for a wider concept of high -level entrepreneurship education and often conceived as having highly practical subject matter with a functional curriculum Basically, it is a process that provides entrepreneurial competencies to provide them with the confidence to operate in any environment [40].

H1: Entrepreneurship curriculum has a direct positive effect on entrepreneurial intent among the Malaysian university students.

\section{ii) Teaching methodologies}

In the field of entrepreneurship teaching, there are many pedagogical methods with a wide range of models, methods, approaches and modalities [41]. The concept of teaching model integrates a number of dimensions related to both the ontological and educational levels [42]. Most business schools appear to use combination of theoretical and practical approaches in entrepreneurial studies [43, 44]

H2: The teaching methodologies have a direct positive effect on entrepreneurial intent among the Malaysian university students.

\section{iii) University's role in promoting entrepreneurship}

The vast majority of students in higher education are not given the opportunity to engage in enterprise education as part of their subject level program studies. Therefore it has been suggested that enterprises and entrepreneurship are learned phenomena and universities play a vital role in encouraging and providing opportunities for enterprise to flourish. The focus is on promoting economic development rather than teaching and research $[45,35]$. 
H3: The University's role in promoting entrepreneurship has a direct positive effect on entrepreneurial intent among the Malaysian university students.

\subsubsection{Mediating variables iv) Attitude factors}

According to the theory of planned behaviour, individual's attitudes have an impact on behaviour via intention. Researchers have proposed models and suggested that perceived desirability, feasibility, subjective (social) norms, attitude, perceived self-efficacy and perceived behavioural control are key factors affecting entrepreneurial intentions [46]. Attitudes can be classified as attitude towards money, attitudes towards change and attitudes towards entrepreneurship [37, 38].

A favourable attitude towards money refers to individuals who view high incomes as a symbol of success (achievement) and as a means to attain autonomy, freedom and power. Such features are often inclined towards successful entrepreneurs [47]. Individuals possessing a positive attitude towards change are characterised primarily by the propensity to view as attractive rather than threatening those situations that are ambiguous, changing rapidly or unpredictable [48] and this is viewed as a factor influencing entrepreneurial motivation positively [24]. The desire to be competitive influences the attitude towards entrepreneurship to act as a primary determinant of students' willingness to be self-employed [39].

H4: Attitude factors have a direct positive effect on entrepreneurial intent among the Malaysian university students.

\section{v) Stakeholder support system factors}

The stake holder's involvement, i.e. the government, financial institutions and parents' of students are crucial to ensure that entrepreneurship flourish in the current revolution [49, 50 \& 51]. Entrepreneurship is enforced by the government through public policies and programs that consider financing to be one of the principal means of achieving higher rates of entrepreneurial activity [52, 53]. Academic entrepreneurs involved in innovation have a high need for financing availability because innovative activities are often costly [54]. Sources of funding obtained from the financial institutions are micro-financing, capital financing and equity [55]. The parents of students as external stakeholders have a vested interest in the welfare and future employment prospect of their children and they provide financial support to their children during their study in the higher educational institutes [56, 57].

H5: Stakeholder support system factors have a direct positive effect on entrepreneurial intent among the Malaysian university students

2.2.3 Endogenous variable

\section{vii) Entrepreneurial intention}

Shapero's model suggested that entrepreneurial intentions were influenced by perceptions of desirability, feasibility and propensity to act, and by exposure to entrepreneurship [58, $59 \& 60]$. It further supported the notions of career socialisation theory [61] which suggested that entrepreneurship education experiences 'could influence the perceived desirability and through enhanced self-efficacy [58, 62]. Researchers focused on assessing the impact of entrepreneurship education programs on students' intentions to start business ventures and on the traditional antecedents of intentions such as attitudes, perceptions of control and selfefficacy [42] and environmental barriers, support factors and the university environment. A hostile environment with good financial support increased the individual's intention towards self-employment [39].

\section{Methodology}

The research approach formulates tests and refines hypotheses and involves a hypo-deductive approach and employs quantitative measurement and use of statistical analysis [63, 64]. The purpose may be to illuminate some process or problem and to suggest a way forward in what may be an ambiguous situation or where there is uncertainty [65]. The research is classified as descriptive and explanatory, as it is set out to confirm a hypothesized relationship between two or more variables. The survey method is used to obtain the trustworthiness of the research thus including the usage of multiple sources of evidence to test the validity and reliability of the findings. The data that has emerged from the questionnaire sample surveys are analysed through SPSS and Structural equation modelling (SEM) techniques.

Structural equation modelling is a statistical methodology which takes a confirmatory) i.e. hypothesistesting approach to analyze a structural theory bearing on some phenomenon. This structural theory is suitable for 'causal' processes that generate observation on multiple variables [66]. The term 'structural equation modelling' conveys two important aspects of the procedures. Firstly that causal processes under the study are 
represented by a series of structural (i.e. regression) equation and secondly that these structural relations can be modelled pictorially to get a clearer conceptualization of the theory under study. The hypothesised model could then be tested statistically in an analysis of the entire system of variables to determine the extent to which it is consistent with the data. If the model fits adequately, it is found to be plausible of postulated relations among variables, if it is inadequate, then the testability of the relation is rejected [67].

The three characteristics of the SEM model could be summarised as follows:

i) Estimation of multiple and interrelated dependence relationships.

ii) An ability to represent unobserved concepts in these relationships and account for the measurement error in the estimation process,

iii) Defining a model to explain the entire set of relationships [68].

The researcher is interested in studying the theoretical constructs that cannot be observed directly. This abstract phenomenon is called 'latent variables' or factors. In the research the latent variable or endogenous variable is entrepreneurial intention among students in the university. Since latent variables are not observed directly they cannot be measured directly. As such the unobserved variable is linked to one that is observable making its measurement possible. Assessment of the behaviour then constitutes direct measurement of the observed variable albeit the indirect measurement of an unobserved variable (i.e. the underlying construct). In this research the exogenous variables of entrepreneurship education which consist the components of entrepreneurship curriculum, teaching methodologies, and role of the university in promoting entrepreneurship are the observed variables. They serve as indicators of the underlying constructs which they represent. The other mediating variables consist of attitude factors, and stakeholder system support factors act as indicators [67].

When SEM is applied, the researcher can assess the contribution of each indicator variable in representing its associated construct and measure how well the combined set of indicator variables represents the construct (reliability and validity). This is the measurement assessment component of SEM. SEM provides a conceptually appealing way to test theory where the researcher can express the theory in terms of relationships among measured variables and latent constructs (variates), and then SEM will assess how well the theory fits as represented by the data [67].

The following are the six stages in SEM:

i) Defining individual constructs

ii) Developing a measurement model.

iii) Designing a study to produce empirical results

iv) Assessing the measurement model validity

v) Specifying the structural model

vi) Assessing the structural model validity

\section{Preliminary Conclusion And Findings}

This study has considered entrepreneurship education as the exogenous variable against the endogenous variable of entrepreneurial intention and demographic, attitude and stakeholder support system as mediating variables. Studies indicated that curriculum for entrepreneurship did not have a significant impact on students' entrepreneurship related ideas, but some programs raised attitudes among students' intentions as at which stage entrepreneurship education was taught to motivate the students' interest in entrepreneurship [69]. It had been noted that traditional teaching methods employed in the classroom settings were changing with the increasing use of technology moving towards a more knowledge sharing ecology [50]. The university's perception showed a positive result in providing adequate knowledge and inspiration for entrepreneurship such as small business management courses and incubators set up in university campuses that increased the students' enthusiasm and interest in entrepreneurship. Attitudes had proven to be important for predicting entrepreneurial aspirations and with the exception of attitude for competitiveness, the others money and change showed significant dispositions. As for stakeholders support system, studies showed that the students as primary stakeholders were directly involved in entrepreneurship education, and other stakeholders were of secondary importance ranging relatively low. No realistic conclusions were drawn in relation to government, other agencies and parents on the impact of entrepreneurship educations [70]. Several limitations were found in the study, the challenge being the data collection process as data collected was cross-sectional. It was suggested that longitudinal data would provide validity research support. Further to this, future research could be oriented to redefine the variables that compose of the educational background in the research. 


\section{References}

[1]. Matlay \& Carey, Entrepreneurship education in the UK a longitudinal perspective, Journal of Small Business and Enterprise Development, 14(2), 252-63, 2007.

[2]. Collins, L., Hannon, P.D., Smith, A., Enacting entrepreneurial intent: the gap between student needs and higher education capability, Education \& Training, 46(8/9), 454-463, 2004.

[3]. Katz, J.A., The chronology and intellectual trajectory of American entrepreneurship education, Journal of Business Venturing, 18(3), 283-300, 2003.

[4]. Fayolle, A., Handbook of Research in Entrepreneurship Education - A General Perspective Volume 1 Cheltenham (UK): Edward Elgar, 2007

[5]. Kuratko, D.F., The emergence of entrepreneurship education: development, trends and challenges, Entrepreeneurship Theory and Practice, 29(5), 577-597, 2005.

[6]. Nurmi, P., and Paasio, K., Entrepreneurship in Finnish Universities, Education \& Training, 49(1), 56-65, 2007.

[7]. Krueger, N. F., Reilly, M. D. \& Carsrud, A. L., Competing models of entrepreneurial intentions, Journal of Business Venturing, 15, 411-432, 2000.

[8]. Vesalainen, J. \& Pihkala, T., Entrepreneurship identity, intentions and the effect of the push-factors, Academy of Entrepreneurship Journal, 5(2), 1-24, 1999.

[9]. Fatoki, O.O.,Graduate Entrepreneurial Intention in South Africa: Motivations and Obstacles, International Journal of Business and Management, 5(9), 87-98, 2010.

[10]. Agbim, C.K., Oriarewo, O.G., \& Owocho, M., Factors influencing entrepreneurial intentions among graduates of Nigerian tertiary institutions, International Journal of Business and Management Invention, 2(4), 36-44, 2013.

[11]. Fong, C. O., The official opening Malaysia Career and Training Fair, viewed April 2006, www.mohr.gov. my/mygoveg/makluman/spm447.htm., 2005.

[12]. Muszafarshah, M. M. \& Woon, From academic knowledge to holistic wisdom: four transformations for institutional reform in higher education, viewed August 2005.

[13]. Mohamed, A. \& Chze C. L., Mobilizing Domestic and External Resources for Economic Development: Lessons from the Malaysian experience, Asia-Pacific Development Journal, 8(1), 41-68, 2001.

[14]. Weaver, M. Dickson, P., Solomon, G., Entrepreneurship and education: what is known and not known about the links between education and entrepreneurial activity. The Small Business Economy for Data Year 2005: A report to the President, United States Government Printing Office, Washington, DC, 2006.

[15]. Turker D., Selcuk S.S., Which factors affect entrepreneurial intention of university students? Journal of European Industrial Training, 33(2), 142-159, 2009.

[16]. Koh, H. C., Factors associated with entrepreneurial inclination: An empirical study of business undergraduates in Hong Kong, Journal of Small Business and Entrepreneurship, 12(2), 29-41, 2005.

[17]. Gurol, Y., Atsan, N., Entrepreneurial characteristics among university students, Journal of Education and Training, 48(1), 25-38, 2006.

[18]. Ajzen, L. \& Fishbein M.0, Understanding Attitudes and Predicting Social Behavior (Prentice Hall, Englewood Cliffs, New Jersey), 1980.

[19]. Malebana, J. Entrepreneurial intentions of South African rural university students: A test of the theory of planned behaviour, Journal of Economics and Behavioral Studies, 6(2), 130-143, 2014.

[20]. McClelland, D. C., The achieving society, Princeton, NJ: Van Nostrand, 1961.

[21]. Ferreira, J.J., Raposo, M.L., Rodrigues, R.G., Dinis, A., \& Paço, A., A model of entrepreneurial intention: An application of the psychological and behavioral approaches, Journal of Small Business and Enterprise Development, 19(3), 424 - 440, 2012.

[22]. Bandura A., Barbaranelli, C. Caprara, G., Pastorelli, C., Self-efficacy beliefs as shapers of children's aspirations and career trajectories, Child Development, 72 (1), 187-206, 2001.

[23]. Babb, E. M., \& Babb, S. V., Psychological traits of rural entrepreneurs, Journal of Socio- Economics, vol. 21, 353-362, 1992.

[24]. Autio, E. Keeley, R.H., Klofsten, M., Entrepreneurial intent among students: testing an intent model in Asia, Scandinavia, and USA, Frontiers of Entrepreneurship Research, Babson College, Wellesley, MA, 1997.

[25]. Veciana, J.M., Aponte, M., Urbano, D., University student's attitudes towards entrepreneurship: A two countries comparison, The International Entrepreneurship and Management Journal, 1(2), 165-182, 2005.

[26]. Krueger, N. F., The impact of prior entrepreneurial exposure on perceptions of new venture feasibility and desirability, Entrepreneurship Theory and Practice 18(1), 5-21, 1993.

[27]. Davidsson, P., Culture, structure and regional levels of entrepreneurship, Entrepreneurship and Regional/Development, vol. 7, 41$62,1995$.

[28]. Kolvereid, L., Isakssen, E., New business start-ups and subsequent entry into self-employment, Journal of Business Venturing, 21, 866-85, 2006.

[29]. Autio, E., Keeley, R.H., Klofsten, M., Parker, G., and Hay, M., Entrepreneurial intent among students in Scandinavia and in the USA, Enterprise and Innovation Management Studies, 2(2), 145-160, 2001.

[30]. Tkachev, A., \& Kolvereid, L. Self-employment intentions among Russian students, Entrepreneurship andRegional Development, 11(3), 379-99, 1999.

[31]. Lee, S.M., S. Pathak, R.D., Chang, D., Li W, Influences on students attitudes toward entrepreneurship: amulti-country study, The International Entrepreneurship and Management Journal, 2(3), 351-66, 2006.

[32]. Linan, F., Chen, Y, Testing the entrepreneurial intention model on a two-country sample, Working Paper 2006/2007, Department of Business Economic, Universitat Autonoma de Barcelona, Barcelona, 2006.

[33]. Thompson, J.L., The facets of the entrepreneur: identifying entrepreneurial potential, Management Decision, 42(2), 243-58, 2004.

[34]. Gibb, A., In pursuit of a new 'enterprise' and 'entrepreneurship' paradigm for learning: creative destruction, new values, new ways of doing things and new combinations of knowledge, International Journal and Management Reviews, 4(.3), 233-69, 2002.

[35]. Gibb, A.,Towards the entrepreneurial university: Entrepreneurship Education as a Lever for Change, Policy Paper No. 003, National Council for Graduate Entrepreneurship, Birmingham, 2005.

[36]. Levie, J., \& Autio, E.. Growth and growth intentions: A meta-analysis of existing evidence. Enterprise Research Centre (ERC), $\begin{array}{llll}\text { White } & \text { Naper } & \text { No.1. anline] railable:http://enterprise research.ac.uk/default/ }\end{array}$ assets/File/ERC\%20White\%20Paper\%20No_1\%20Growth\%20final.pdf. 2014.

[37]. Douglas, E.J., Entrepreneurship as a career choice: attitudes, entrepreneurial intentions, and utility maximisation, Frontiers of Entrepreneurship Research, Babson College, Wellesley, M.A., 1999. 
[38]. Robinson, P., Stimpson, D.V., Huefner, J. C., \& Hunt, H. K., An Attitude Approach to Prediction of Entrepreneurship, Entrepreneurship Theory and Practice, 15(1), 13-31, 1991.

[39]. Franke, N. \& Luthje, Entrepreneurship intentions of business students: A benchmarking study, viewedOctober 23 2003, www2.wuwien.ac.at/entrepren/modules? 2004.

[40]. Oyugi, J. L., Effectiveness of the methods of teaching entrepreneurship courses to developing self-Efficacy and intention among university students in Uganda, International Journal of Social Sciences and Entrepreneurship, 1 (11), 491-513, 2014.

[41]. Zahra, A, Manasoreh K. F, and Narges, I, A Study of Teaching Methods in Entrepreneurship Education for Graduate Students, Higher Education Studies, University of Tehran. 2(1), 2012.

[42]. Fayolle, A. \& Gailly, B, From crafts to science, Journal of European Industrial Training, 32(7), 569-593, 2008.

[43]. Timmons, J., Spinelli, S., New Venture Creation: Entrepreneurship for the 21st century, 9th edition, McGraw-Hill Irwin, New York, NY, 2011.

[44]. Peterman, N., Kennedy, J., Enterprise education: influencing students' perceptions of entrepreneurship, Entrepreneurship, Theory and Practice, 28(1), 129-44, 2003.

[45]. Hegarty, C. It's not an exact science: teaching entrepreneurship in Northern Ireland, Education \&Training48(5), 322-35, 2006.

[46]. Pratheeba P., Predicting entrepreneurial intention among business and engineering students in Sri Lanka, Ruhuna Journal of Management and Finance, 1(1), 2014.

[47]. Lim, V., Teo, T. Sex, money and financial hardship: an empirical study of attitudes towards money among undergraduates in Singapore, Journal of Economic Psychology, 18, 369-86, 2003.

[48]. Shane, S., Locke, E.A., Collins, C.J., Entrepreneurial motivation, Human Resources Management Review, 13(2), 257-79, 2003.

[49]. Hannon, P., Teaching pigeons to dance: sense and meaning in entrepreneurship education, Education \& Training, 48 (5) 296308, 2006.

[50]. Solomon, G.T. An examination of entrepreneurship education in the United States, Journal of Small Business and Enterprise Development, 14 (2), 168-87, 2007.

[51]. Jones, C., Creating the reasonable adventurer: the co-evolution of students and learning environment, Journal of Small Business and Enterprise Development, 14 (2), 195-225, 2007.

[52]. Reynolds, P.N. Bosma, E. Autio, S. Hunt, N. De Bono, I. Servais, P. Lo’ pez-Garc1'a, and N. Chin, Global Entrepreneurship Monitor: Data collection design and implementation 1998-2003, Small Business Economics vol. 24, 205-31, 2005.

[53]. Stevenson, L., and A. Lundstro" m, Entrepreneurship policy for the future: Best practice Components, In Keystones of entrepreneurship knowledge, ed. R. Van Der Horst, S. Kingkauanui, and S. Duffy, 177-94. Oxford: Blackwell Publishing, 2005.

[54]. Green, P.G., \& Brown, T.E., Resource needs and the dynamic capitalism typology. Journal of Business Venturing, 12 (3), 161-173, 1997.

[55]. Fehr, D., \& Hishigsuren, G., Raising capital for microfinance: sources of funding and opportunities for equity financing, Journal of Development Entrepreneurship, 11(2), 133-143, 2006.

[56]. Matlay, H., Entrepreneurship education in the U.K., Journal of Small Business and Enterprise Development, 16 (2), 355 -368, 2009.

[57]. Geldhof, G. J., Weiner, M., Agans, J. P., Mueller, M. K., \& Lerner, R. M., Understanding entrepreneurialintent in late adolescence: The role of intentional self-regulation and innovation, Journal of Youth and Adolescence, 43, 81-91, 2014.

[58]. Shapero, A. The displaced uncomforatable entrepreneur, Psychology Today, 9, 83- 8, 1975

[59]. Shapero, A. Sokol, L., The social dimensions of entrepreneurship, in Kent C., Sexton, D., Vesper, K. (Eds), The Encyclopedia of Entrepreneurship, Prentice-Hall, Englewood Cliffs, NJ, 72-90, 1982.

[60]. Bird, B., Implementing entrepreneurial items, the case of intention, The Academy of Management Review13(3), 442-453, 1988.

[61]. Dyer Jr., Gibb, W., Toward a Theory of Entrepreneurial Career, Entrepreneurship: Theory \& Practice, Winter 94, 19 (2), 7-21, 1994.

[62]. Boyd, N.G., \& Vozikis, G.S., 'The influence of self-efficacy on the development of entrepreneurial intentions and actions', Entrepreneurship Theory and Practice, (18)4, 63-74, 1994.

[63]. Neuman, W. L., Social Research Methods, Qualitative and Quantitative Approaches, 7th edition, published by Pearson Education Inc. USA, 2010.

[64]. Cresswell, J.W., Research Design Qualitative, Quantitative, and Mixed Methods Approaches, 3nd edition, Sage Publications Inc., USA, 2007.

[65]. Zikmund, W.G., Business Research Methods, published by Thompson South Western Publication, 9 th edition, 2010.

[66]. Bentler, P. M., Causal modeling via structural equation systems, in J.R. Nesselroade \& R.B. Cattell (Eds), Hanbook of multivariate experimental psychology, 2nd edition, 317-335, New York: Plenum, 1988.

[67]. Byrne, B.M., Structural Equation Modelling, Basic Concepts, Applications, and Programming, publishedby Lawrence Erlbaum Associates, Inc., 2013.

[68]. Hair, J.F., Jr., Black, W.C., Babin, B.J., Anderson, R.E., 'Multivariate Data Analysis, A Global Perspective 7th edition, Pearson publications, 2014.

[69]. Souitaris, V. Zerbinati, S. Al-Laham, A., Do entrepreneurship programmes raise entrepreneurial intentionof science? The effect of learning, inspiration and resources, Journal of Business Venturing, 22 (4), 566-91, 2007.

[70]. Schewarz, E.J., Wdowiak, M.A., Almer-Jarz, D.A. \& Breitnecker, R.J., The effects of attitudes and perceived environment conditions on students' entrepreneurial intent, Journal of Education and Training, 51(4), 272-291, 2009. 